\title{
Kardiyopulmoner Bypass'ın Hemogram Parametreleri Üzerine Etkisi
}

\section{The Effect of Cardiopulmonary Bypass on Hemogram Parameters}

\author{
${ }^{1}$ Bişar AMAÇ, ${ }^{2}$ Aydemir KOÇARSLAN, ${ }^{3}$ Mehmet Salih AYDIN, ${ }^{3}$ Nazım KANKILIÇ, \\ ${ }^{4}$ Mahmut PADAK, ${ }^{5}$ Reşat DİKME

\begin{abstract}
${ }^{1}$ Sağlık Bilimleri Üniversitesi, Şanlıurfa Mehmet Akif İnan Eğitim ve Araştırma Hastanesi, Perfüzyon Birimi, Şanlıurfa, Türkiye ${ }^{2}$ Kahramanmaraş Sütçü İmam Üniversitesi Tıp Fakültesi Kalp ve Damar Cerrahisi Anabilim Dalı, Kahramanmaraş, Türkiye ${ }^{3}$ Harran Üniversitesi Tıp Fakültesi Kalp ve Damar Cerrahisi Anabilim Dalı, Şanlıurfa, Türkiye

${ }^{4}$ Harran Üniversitesi Sağlık Hizmetleri Meslek Yüksekokulu, Perfüzyon Teknikleri Programı, Şanlıurfa, Türkiye

${ }^{5}$ Harran Üniversitesi Sağlık Hizmetleri Meslek Yüksekokulu, Diyaliz Programı, Şanlıurfa, Türkiye
\end{abstract}

Bișar Amaç: https://orcid.org/0000-0003-0320-4239

Aydemir Koçarslan: https://orcid.org/0000-0003-3874-8762

Mehmet Salih Aydın: https://orcid.org/0000-0002-6652-6035

Nazım Kankılıç: https://orcid.org/0000-0001-7111-7503

Mahmut Padak: https://orcid.org/0000-0001-6863-1907

Reşat Dikme: https://orcid.org/0000-0001-9157-7830

\section{ÖZ}

Amaç: $\mathrm{Bu}$ çalışmada, kardiyopulmoner bypass yöntemi ile kardiyovasküler cerrahi geçiren hastaların farklı zamanlarda alınan hemogram örneklerinin değerlendirilmesi amaçlanmıştır.

Materyal ve Metot: Prospektif olan çalışmamıza çeşitli sebeplerden dolayı kardiyovasküler cerrahi geçiren 30 hastadan preoperatif, anestezi indüksiyonu sonrası, aortik kross klemp sonrası, KPB çıkışından hemen sonra ve postoperatif 5.gün olmak üzere beş farklı zamanda hemogram tüpüne kan örnekleri alındı. Numuneler tam kan sayım cihazında çalışıldı ve istatistiksel analizleri yapıldı.

Bulgular: Çalışmaya dahil edilen hastaların yaşları $49,57 \pm 14,25$, boylar1 $165,33 \pm 0,06 \mathrm{~cm}$, kilolar1 $71,00 \pm 12,98 \mathrm{~kg}$, aortik kross klemp süreleri $75,23 \pm 28,45$ dakika, total perfüzyon süreleri $112,50 \pm 46,23$ dakika, hastanede kalış süreleri $13,53 \pm 10,18$ gün, yoğun bakım kalış süreleri $1,9 \pm 2,04$ gün, vücut yüzey alanları $1,78 \pm 0,17 \mathrm{~m}^{2}$, flow değerleri $4177,90 \pm 831,91 \mathrm{ml} / \mathrm{dk} / \mathrm{m}^{2}$ bulundu. Lökosit, lenfosit, monosit, eoznofil, eritrosit, hematokrit ve platelet düzeylerindeki değişim istatistiksel olarak anlamlı bulundu $(\mathrm{p}<0,05)$. Nötrofil, bazofil ve hemoglobin düzeylerinde de ciddi düzeyde değişim vardı ancak istatistiksel olarak anlamlı değildi $(\mathrm{p}>0,05)$.

Sonuç: Kardiyopulmoner bypass yöntemi ile kardiyovasküler cerrahisi sırasında uygulanan hemodilüsyon, heparinizasyon ve kanın endotel olmayan yüzeylerle teması neticesinde hasar ve enflamatuar yanıta bağl1 olarak hemogram parametrelerinde ciddi düzeyde değişimler oluşmaktadır.

Anahtar Kelimeler: Ekstrakorporeal dolaşım, hemogram parametreleri, kardiyopulmoner bypass, perfüzyon

\section{ABSTRACT}

Objective: This study aims to evaluate the hemogram samples taken at different times from patients who underwent cardiovascular surgery with cardiopulmonary bypass method.

Materials and Methods: In this prospective study, blood samples were taken from 30 patients who underwent cardiovascular surgery for various reasons at five different times: preoperatively, after anesthesia induction, after aortic cross clamp, immediately after CPB, and on the postoperative 5th day. Complete blood count was performed for the samples and statistical analysis was made.

Results: The patients were found to have the following values: age $49.57 \pm 14.25$ years, height $165.33 \pm 0.06 \mathrm{~cm}$, weight $71.00 \pm 12.98 \mathrm{~kg}$, aortic cross clamp time $75.23 \pm 28.45$ minutes, total perfusion time $112.50 \pm 46.23$ minutes, hospital stay $13.53 \pm 10.18$ days, intensive care stay $1.9 \pm 2.04$ days, body surface areas $1.78 \pm 0.17 \mathrm{~m}^{2}$, flow values $4177.90 \pm 831.91 \mathrm{ml} / \mathrm{min} / \mathrm{m}^{2}$. The change in leukocyte, lymphocyte, monocyte, eosinophil, erythrocyte, hematocrit and platelet levels was statistically significant $(p<0.05)$. There was also a significant change in neutrophil, basophil and hemoglobin levels, but it was not statistically significant ( $\mathrm{p}>0.05)$.

Conclusion: As a result of hemodilution, heparinization and blood contact with non-endothelial surfaces during cardiovascular surgery with cardiopulmonary bypass method, serious changes in hemogram parameters occur due to damage and inflammatory response.

Keywords: Cardiopulmonary bypass, extracorporeal circulation, hemogram parameters, perfusion
Sorumlu Yazar / Corresponding Author:

Bişar Amaç

Sağlık Bilimleri Üniversitesi, Şanlıurfa Mehmet Akif İnan Eğitim ve Araştırma Hastanesi, Perfüzyon Birimi, Şanlıurfa, Türkiye Tel: +905459120063

E-mail: amacbisar@gmail.com
Yayın Bilgisi / Article Info:

Gönderi Tarihi/ Received: 17/10/2020

Kabul Tarihi/ Accepted: 16/11/2020

Online Yayın Tarihi/ Published: 05/03/2021

Atıf / Cited: Amaç B, ve ark. Kardiyopulmoner Bypass'ın Hemogram Parametreleri Üzerine Etkisi. Online Türk Sağlık Bilimleri Dergisi 2021;6(1):102-111. doi: $10.26453 /$ otjhs.811833 


\section{GİRIŞ}

Günümüzde ölüm nedenleri arasında en sık kardiyovasküler hastalıklar yer almakta ve önümüzdeki yıllarda da böyle olması beklenmektedir. Koroner arter hastalığı (KAH), tüm dünyada yüksek mortalite ve morbidite ile ilişkili en yaygın kardiyovasküler hastalık şeklidir. ${ }^{1}$

Kardiyopulmoner bypass (KPB), ameliyat sirasinda kalp ve akciğerlerin işlevini geçici olarak devralan, kan dolaşımını ve vücudun oksijen içeriğini vücudun dişında sağlayan koruyucu bir tekniktir. Bu teknik, tıp biliminde kalp cerrahlarının kapak değişimi, konjenital anomalilerin onarım1, koroner bypass cerrahisi ve bazı büyük anevrizma ameliyatları, pulmoner embolektomi ve kalp nakli gibi birçok açık kalp ameliyatlarının gerçekleştirilmesine izin veren devrim niteliğinde bir yenilik olmuştur. ${ }^{2}$ Bununla birlikte, KPB ile kalp cerrahisi geçiren hastaların aşırı perioperatif kan kaybı ve postoperatif anemi, sarılık ve enfeksiyon durumlarına karşın risk faktörlerinin artmış olduğu gözlenmiş, ancak bu zarar verici faktörleri en aza indirmek için kapsamlı çalışmalar için büyük çaba sarf edilmiştir. ${ }^{3}$

Kardiyopulmoner bypass sırasında kanın nonfizyolojik yüzeyle etkileşimi, hipotermi, nonpulsatil akıma sistemik inflamatuar yanıt ve kalbe kross klemp konmasına bağlı olarak kardiyak iskemi reperfüzyon hasarı (İRH) meydana gelmektedir. $^{4}$

Kalp cerrahisi geçiren hastaların postoperatif dönemde karşılaşabilecekleri risklerin öngörülmesi postoperatif dönemdeki hasta bakım kalitesini artırmanın ilk adımı olarak kabul edilmektedir. ${ }^{5}$ Kardiyopulmoner bypass esnasında bazı organ ve sistemlerde fonksiyon kayıpları meydana gelebilmektedir. Bununla birlikte mortalite ve postoperatif dönemde morbidite riski artmaktadır. ${ }^{6}$ Ayrıca cerrahi esnasında travmaya bağlı artmış sistemik inflamatuar yanıt oluşabilmekte, gelişen bu inflamatuar yanıt da postoperatif dönemde birçok komplikasyonu beraberinde getirmektedir. Kardiyopulmoner bypass sirasinda meydana gelen inflamatuar yanıtın etkisi ile birçok kan parametresi etkilenmekte ve etkilenen bu parametreler istenmeyen komplikasyonlara sebep olabilmektedir. Ayrıca kardiyopulmoner bypass'ın dilüsyonel etkisiyle veya kanın hava ve pompa hatlarındaki diğer materyallerle temas etmesine bağlı olarak trombosit bozukluğu ortaya çıkabilmektedir. ${ }^{7,8}$ Güncel olarak, hemogram parametrelerinden elde edilen nötrofil lenfosit oranı (NLO) ve platelet lenfosit oranı (PLO) gibi paramet- reler son dönemlerde inflamatuar belirteçlerin yeni birer ifadesi olarak birçok hastalıkta araştırılmıştır. İnflamatuar sürecin rolü nedeniyle bu parametreler vasküler hastalıklarda da incelenmektedir. ${ }^{9-11}$

Çalışmamızın amacı, KPB yöntemi ile ameliyat olan hastaların; ekstrakorporeal dolaşım (EKD) öncesinde, sırasında ve sonrasında olmak üzere farklı zamanlarda alınan hemogram örneklerinin değerlendirilmesi amaçlanmıştır.

\section{MATERYAL VE METOT}

Çalışma için Harran Üniversitesi Tıp Fakültesi Klinik Araştırmalar Etik Kurulundan onay alındı (Tarih:23.11.2015, karar no:07). Tüm hastalar Helsinki Deklarasyonuna uygun olarak uygulanacak tedavi konusunda bilgilendirildi ve hastalardan bilgilendirilmiş onam formu alınd.

$\mathrm{Bu}$ prospektif çalışmaya Harran Üniversitesi Tıp Fakültesi Araştırma ve Uygulama Hastanesi Kalp ve Damar Cerrahisi polikiniğine çeşitli sebeplerden dolayı başvuran ve KPB yöntemi kullanılarak elektif açık kalp cerrahisi (koroner arter greftleme, kapak replasmanı-tamiri) uygulanan 15 erkek ve 15 kadın toplam 30 hasta dahil edildi. Bu hastalardan preoperatif (ilk servise yatışta), anestezi indüksiyonu sonrası (santral venöz basınç kataterinden), aortik kross klemp sonrası, KPB çıkışından hemen sonra ve postoperatif 5. gün olmak üzere beş farklı zamanda alınan hemogram kan örnekleri - (eksi) $80{ }^{\circ} \mathrm{C}$ 'de saklandı. Çalışma gününde numuneler tam kan sayım cihazında Lökosit (WBC), Nötrofil (NEU), Lenfosit (LYM), Monosit (MONO), Eozinofil (EOS), Bazofil (BASO), Eritrosit (RBC), Hematokrit (HCT), Hemoglobin (HGB) ve Platelet (PLT) düzeyleri çalışıldı.

Çalışmamızda Harran Üniversitesi Tıp Fakültesi Araştırma ve Uygulama Hastanesi Tıbbi Biyokimya Laboratuvarı'nda rutin olarak kullanılan cihazlardan yararlanıldı. Hemogram parametreleri lazer yöntemiyle çalışıldı.

Ameliyat öncesi hemogram parametrelerini etkileyebilecek komorbid hastalığı olanlar çalışma dışı bırakıldı. Dışlama kriterleri uygulandıktan sonra ardışık olarak ameliyat edilen hastalar çalışmaya dahil edildi.

Ístatistiksel Analizler: İstatistiksel analizler SPSS ${ }^{\circledR}$ Versiyon 16.0 (SPSS Inc. Chicago USA) bilgisayar programı kullanılarak gerçekleştirilmiştir. Olgu sayısı power analiz ile saptandı. Sürekli ve sıralı veriler için ortalama ve standart sapmalar hesaplandı. Normallik dağılımını değerlendirmek 
için Kolmogorov Smirnov testi ve Shapiro-Wilk testi kullanıldı. Normal dağılıma uygun görülen hemogram parametrelerinin farklı zamanlardaki değerleri arasındaki farkın önemi ANOVA testi kullanılarak yapıldı, parametrelerin herhangi iki farklı zamandaki değeri arasındaki farkın önemi Eşleştirilmiş t-testi kullanılarak yapıldı. Hemogram parametreleri ile ilişkili faktörler arasındaki ilişki Pearson Korelasyon analizi ile belirlendi. $\mathrm{p}<0.05$ 'den küçük değerler istatistiksel olarak anlamlı kabul edildi.

\section{BULGULAR}

Çalışmaya dahil edilen hastaların yaş ortalaması $49,57 \pm 14,25 \mathrm{idi}$, ortalama boyları $165,33 \pm 0,06 \mathrm{~cm}$, ortalama kiloları $71,00 \pm 12,98 \mathrm{~kg}$, ortalama aortik kross klemp süreleri $75,23 \pm 28,45$ dakika, ortalama total perfüzyon süreleri $112,50 \pm 46,23$ dakika, ortalama hastanede kalış süreleri 13,53 $\pm 10,18$ gün, ortalama yoğun bakım kalış süreleri 1,9 $\pm 2,04$ gün, ortalama vücut yüzey alanları $1,78 \pm 0,17 \mathrm{~m}^{2}$, ortalama flow değerleri $4177,90 \pm 831,91 \mathrm{ml} / \mathrm{dk} / \mathrm{m}^{2}$ bulundu (Tablo 1).

Lökosit (WBC), lenfosit (LYM), monosit (MONO), eoznofil (EOS), eritrosit (RBC), hematokrit (HCT) ve platelet (PLT) düzeylerindeki değişim istatistiksel olarak anlamlı bulundu $(\mathrm{p}<0,05)$. Nötrofil (NEU), bazofil (BASO) ve hemoglobin (HGB) düzeylerindeki değişimde istatistiksel olarak anlamlı fark yoktu ( $>00,05)$. Lökosit (WBC), lenfosit (LYM), monosit (MONO), eoznofil (EOS), bazofil (BASO), eritrosit (RBC), hematokrit (HCT) ve hemoglobin (HGB) düzeyleri kross klemp sonrası döneme kadar azalmaya devam etti, KPB çıkışından itibaren yeniden normal düzeylerine doğru yükselmeye başladı. Nötrofil (NEU) ve platelet (PLT) düzeyleri ise KPB çıkışındaki dönemde de azaldı, ancak postopreatif 5 . günde kontrol edilen sonuçlarda yükseldiği görüldü (Tablo 2).

Hemogram parametreleri ile KPB sırasında verilen sıvı miktarı, sıvı çıkış miktarı ve sıvı dengesi arasında korelasyon ilişkisi değerlendirildi. KPB sırasında verilen sıvı miktarı ile WBC ve NEU düzeyi arasında pozitif bir korelasyon bulundu (Sirasiyla $\mathrm{r}=0,328$, $\mathrm{p}=0,000 ; \mathrm{r}=0,416 \mathrm{p}=0,000)$. KPB sirasinda verilen sıvı miktarı ile LYM, MONO, EOS, RBC, HCT ve PLT düzeyi arasında negatif bir korelasyon bulundu (Sirasiyla $r=-0,233, p=0,010 ; r=-0,417, p=0,000 ; r=-$ $0,292, \quad \mathrm{p}=0,001 ; \mathrm{r}=-0,715, \quad \mathrm{p}=0,000 ; \mathrm{r}=-0,626$, $\mathrm{p}=0,000 ; \mathrm{r}=-0,526, \mathrm{p}=0,000)$. KPB sirasinda verilen sıvı miktarı ile HGB düzeyi arasında arasında negatif bir ilişki saptandı fakat istatistiksel olarak anlamlı değildi ( $\mathrm{r}=-0,055 \mathrm{p}=0,549)$. KPB sırasındaki sıv1 çıkış miktarı ile WBC, NEU, MONO, RBC, HCT ve HGB düzeyi arasında negatif bir korelasyon saptandi fakat istatistiksel olarak anlamlı değildi (Sırasıyla $\mathrm{r}=-0,028, \mathrm{p}=0,734 ; \mathrm{r}=-0,035, \mathrm{p}=0,671 ; \mathrm{r}=-0,011$, $\mathrm{p}=0,893 ; \mathrm{r}=-0,065, \mathrm{p}=0,428 ; \mathrm{r}=-0,008, \mathrm{p}=0,919 ; \mathrm{r}=-$ $0,008, \mathrm{p}=0,919)$. KPB sırasındaki sıvı çıkış miktarı ile EOS, LYM düzeyi arasında pozitif bir korelasyon saptand 1 fakat istatistiksel olarak anlamlı değildi (Sirasiyla $\mathrm{r}=0,014, \mathrm{p}=0,868 ; \mathrm{r}=0,016, \mathrm{p}=0,849$ ). KPB sırasındaki sıvı çıkış miktarı ile PLT düzeyi arasında pozitif bir korelasyon bulundu $(\mathrm{r}=0,273$, $\mathrm{p}=0,001)$. Sivı dengesi ile $\mathrm{WBC}$ ve NEU düzeyi arasında pozitif bir korelasyon bulundu (Sirasiyla $\mathrm{r}=0,288, \mathrm{p}=0,001 ; \mathrm{r}=0,374, \mathrm{p}=0,000)$. Siv1 dengesi ile LYM, MONO, EOS, RBC, HCT ve PLT düzeyi arasinda negatif bir korelasyon bulundu (Sirasiyla $\mathrm{r}=$ $-0,231, \quad \mathrm{p}=0,011 ; \mathrm{r}=-0,424, \quad \mathrm{p}=0,000 ; \mathrm{r}=-0,284$, $\mathrm{p}=0,002 ; \mathrm{r}=-0,680, \mathrm{p}=0,000 ; \mathrm{r}=-0,593, \mathrm{p}=0,000 ; \mathrm{r}=-$ $0,490, p=0,000)$. Sıv1 dengesi ile HGB düzeyi arasında negatif bir ilişki saptandı fakat istatistiksel olarak anlamlı değildi $(\mathrm{r}=-0,056 ; \mathrm{p}=0,547)$ (Tablo 3).

\section{TARTIŞMA VE SONUÇ}

Kardiyopulmoner bypass eşliğinde yapılan kardiyak cerrahi operasyonları günümüzde koroner arter hastalığı ve bir çok kardiyak hastalığın tedavisinde önemini korumaktadır. Bu operasyonlar başarıyla gerçekleştirilmekte olup olası risk faktörlerinin ortaya konması oldukça önemlidir. Kardiyopulmoner bypassa bağlı hemogram değerlerinin düşmesi; cerrahi kanamaya, hemodilüsyona ve ekstrakorporeal dolaşım sistemine bağlı hasar nedeniyle görülebilmektedir. Kardiyak cerrahide masif kan kaybına bağlı olarak hastane morbidite ve mortalitesi artış göstermektedir.

$\mathrm{Bu}$ güncel çalışmada benzer kardiyak hastalığı olan hastalarda peroperatif hemogram parametrelerindeki değişimi ve bu değişimi etkileyen faktörleri araştırmayı amaçladık. Bu çalışmada elde edilen en önemli bulgu kardiyopulmoner bypass cerrahisinin hemogram parametrelerinde ciddi derecede düşüşe yol açtığının tespit edilmesidir. Diğer önemli bulgular ise: Hemodilüsyon ve hastanın heparinize edilmesi sonucu hemogram parametelerinde düşüş olduğunun; yabancı materyal ile temas sonucu hasar ve enflamatuar yanıta bağlı hemogram parametrelerinde değişimlerin olduğunun tespit edilmiş olmasıdır. $\mathrm{Bu}$ elde ettiğimiz sonuçlar çalışmamızın üstünlüklerini göstermektedir. KPB'da prime solüsyon kullanmanın amacı; hatlar, oksijenatör ve 
filtrelerde bulunan havanın tahliye edilmesini sağlayarak hastaya bağlantıyı yapmak ve hemodilüsyon ile hematokrit değerini düşürerek mikro perfüzyonu artırmaktır. Ameliyat öncesinde yetişkin hastalar da kana ilaveten kullanılan prime solüsyonu nedeniyle kan parametrelerinde azalma yaşanmaktadir.

Roller pompa ve aspirasyon devrelerinde kanın hız değişimlerine uğraması, arteriyel kanülün etrafinda kavitasyon oluşturmasıyla kanın şekilli elemanları üzerinde travma meydana getirebilmektedir. Kanın en büyük şekilli elemanları lökositler olduğu için kanın ani hızlanması ve yavaşlamasından özellikle etkilenirler. Kardiyopulmoner bypass sirasinda lökositlerin sayısında önemli değişiklikler meydana gelmektedir. Vasküler sistemin dişına lökositlerin geçici olarak hareket etmelerinin sonucu bu durum oluşmaktadır. $^{5}$

Lökositler, KPB'da vücut inflamatuar yanıtının birçok tablosunun temelini oluşturmaktadır. KPB esnasında ve sonrasında başlayan immün yanıt, organların fonksiyon kaybina neden olmaktadır. Lökositler immün yanıtın başlaması ve devam etmesinde etkilidir. Lökosit sayısı KPB başlangıcında hemodilüsyona bağlı olarak azalsa bile kardiyopulmoner bypass süresince inflamatuar yanıta bağlı olarak sayıları artmaktadır. Ayrıca lökosit ve alt parametre sayılarının KPB sirasında azalması ile beraber lökositlerin fonksiyonlarında da azalma olduğu bildirilmiştir. Yapılan bu çalışmada, kardiyopulmoner bypass sonras1 post-operatif 24-28 saat sonra lökosit sayısı 12bin-24bin $10^{3 / \mathrm{uL}}$ 'e ulaştı ğ bildirilmiştir. ${ }^{5}$ Çalışmamızdaki değerlerin bununla uyumlu değerler de olduğunu bulduk. Çalışmamızda KPB çıkışı lökosit değeri 14bin $10^{3 / \mathrm{uL}}$, postoperatif 5 . gün değeri de 13 bin $10^{3 / \mathrm{uL}}$ olarak görüldü.

KPB için ameliyat öncesi risk faktörlerinin belirlenmesi oldukça önemlidir. Bu risk faktörlerinin belirlenmesinde son dönemde karşımıza nötrofil, lenfosit ve trombosit oranları çıkmaktadır. Ayrıca yüksek kardiyovasküler riski olan hastalarda ameliyat öncesi risk tahmininin doğruluğu sınırlıdır. Trombosit/lenfosit oranı (PLO) ve nötrofil/lenfosit oranı (NLO), sistemik inflamasyonu gösterir. Bu her iki oranda kardiyovasküler cerrahide sonuçların tahmini ve kardiyovasküler olayların risk tahmini ile ilişkilidir. Ayrıca NLO'nun ameliyat öncesi risk sınıflandırması için ek bir değer olduğu bilinmektedir. $^{12,13}$

KPB esnasında akut inflamasyon alanlarında yer alan diğer hücreler de genel olarak lökositler tarafın- dan oluşturulan interlökinleri oluşturabilmektedir. $\mathrm{Bu}$ madde KPB sırasında ve sonrasında lökosit alt parametrelerinde artışa sebep olmaktadır. Kardiyopulmoner bypass cerrahisi sonrası ilk aylarda inflamatuar mekanizmalar aktive olur ve trombotik komplikasyonlar ortaya çıkar. $\mathrm{Bu}$ nedenle, kardiyopulmoner bypass cerrahisinden sonra trombosit aktivasyonu ve trombosit-lökosit etkileşimlerindeki değişiklikler oldukça önemlidir. ${ }^{14}$ Ivert ve ark. ${ }^{14}$ yaptıkları çalışmalarında elektif koroner bypass cerrahisi sonrasi artan trombosit reaktivitesi ve trombosit-lökosit agregasyonunu araştırmışlardır. Çalışmalarında ilk postoperatif seyir sırasında beyaz kan hücresi sayılarının arttığını, trombosit sayılarının ise bir ay sonra arttı̆̆ını belirtmişlerdir. Platelet P-selektin ekspresyonunun uyarılmaya bağlı üç ayda önemli ölçüde arttığını belirtmişlerdir.

KPB ile lökositlerde meydana gelen değişim ve lökositlerin sayısının azalması ameliyat sonrasında immün sistemin zayıflamasına neden olmaktadır. Kardiyopulmoner bypassin bu istenmeyen yönleri ile kardiyopulmoner bypassın süresi aynı oranda artmaktadır. ${ }^{6}$ Bilal ve ark. ${ }^{15}$ lökosit sayısının, ameliyat sırasında preoperatif değerlere göre azaldığını, post-operatif dönemde tekrar yükselerek normal değerlere ulaştığını belirtmişler. Rychly ve ark. ${ }^{16}$ kardiyopulmoner bypass sırasında lökosit sayılarının azaldığını, KPB sonrası lökosit sayılarında artışlar olduğunu belirtmişlerdir. Bizim çalışmamızda da KPB sırasında lökosit sayısının azaldığı, KPB çıkışından itibaren ise arttığını saptadık. Çalışmamızda lökosit değeri preoperatif evrede normal değerdeyken prime solüsyon, verilen sıvılar ve KPB sisteminin komponentlerine teması ve sistemin oluşturduğu travma ve hasar nedeni ile belli bir miktar azaldığını gözlemledik. KPB sonrası lökosit düzeyinde ciddi bir yükselme olduğu, bu yükselmenin yabancı materyal ile temas sonrası oluşan inflamatuar yanıt sonucu olabileceğini düşündük.

Hematokrit ve eritrosit değerindeki değişimleri sadece homodilüsyona bağlamak doğru değildir. Vücudun oksijen dengesini belirleyen; bypass sicaklığı, yeniden 1sınma, pompa akımı, perfüzyon süreleri ve perfüzyon basınçları da hemoglobin düzeyini etkileyen etmenlerdir. ${ }^{17-19}$

Kalp-akciğer makinesinden kaynaklanan mekanik travmayı araştıran Lohrer ve ark. ${ }^{20}$ KPB sırasında hemolizin oluşmasına yalnızca mekanik travmanın sebep olmadığını, diğer faktörlerin de rol aldığını belirtmişlerdir. Bizim çalışmamızda preoperatif ortalama eritrosit (RBC) değeri $5.0510^{6 / 4 L_{1}}$ te iken aortik kross klemp sonrası düzeyinde ciddi bir azalma 
olduğu ve ortalama eritrosit değerinin $2.9710^{6 / \mathrm{uL}}$ olduğu görüldü. Bunun temel sebebinin prime solüsyon, verilen sıvılar, perfüzyon süresi ve basınçları, mekanik travma ve hemoliz olduğunu düşündük. KPB sonrasında eritrosit düzeyinde artış olduğu, bu artışın postoperatif 5. günde de devam ettiği görüldü. $\mathrm{Bu}$ artışın sebebinin ise eritrosit replasmanı olabileceğini düşündük.

KPB'ın hematolojik sistemde istenmeyen en önemli komplikasyonunun hemoliz olduğu belirtilmiştir. Hemolizin sebebi de travma ve birçok farklı sebep olmaktadır. Yapılan çalışmalarda hematokritin KPB sırasında azaldığını, eritrosit replasmanı gerektiği belirtilmiştir. ${ }^{20,21}$ Kalp cerrahisinde intraoperatif kan ürünü kullanım sıklığı hasta özellikleri ve cerrahi tipine göre değişmektedir. İleri yaş, kadın cinsiyet, aortik kross klemp/KPB süresinin uzaması, giriş hemoglobin/hematokrit değerlerinin düşük olması ve operasyonun tipi eritrosit süspansiyonu kullanımını arttırmaktadır. Ayrıca eritrosit süspansiyonu kullanımının yüksek olduğu olgularda mortalitenin de arttığı bildirilmiştir. ${ }^{22}$ Kalender ve ark. ${ }^{23}$ yaptıkları çalışmalarında koroner arter bypass greft cerrahisi sırasında yapılan kan transfüzyonunun hastane mortalitesi üzerine olumsuz etkisi olduğunu belirtmişlerdir. $\mathrm{Bu}$ nedenle peroperatif dönemde tranfüzyondan kaçınmak için gerekli önlemlerin alınmasının uygun olacağını belirtmişlerdir. Bizim çalışmamızda hematokrit (HCT) değerleri literatürle uyumlu bulunmuştur. Yaptığımız çalışmada hematokrit (HCT) preoperatif evrede ortalama \%41,28'te iken KPB ile ilişkili faktörler nedeniyle belli bir miktar azaldığını gördük. Aortik kross klemp sonrasında ortalama hematokrit değerinin \%24,91 seviyelerine kadar düştüğünü gözlemledik. KPB sonrası düzeyinde artış olduğu, bu artışın sebebinin ise eritrosit replasmanı olabileceğine kanaat getirdik.

Platelet (PLT), KPB sirasinda trombin tarafindan aktive olmaktadır. Aktifleşen bu trombositlerin yapıları bozulur, sentetik yüzeylere yapışma ilgisi artar ve içerdikleri granüllerde bulunan çeşitli maddeleri bırakırlar. Granüllerde, çeşitli kemotaktikler ve koagülasyona neden olan proteinler ve faktörler bulunmaktadır. Bunlar kapiller permeabilitenin artışını ve düz kas hücrelarinin proliferasyonunu gerçekleştirmekten sorumludur. ${ }^{24} \mathrm{KPB}$ sonunda hemodilüsyon, adezyon ve agregasyon nedeniyle total trombosit sayısında \%30-50 oranında bir azalma meydana gelmektedir. Yapılan çalışmalar sonucunda trombosit sayısındaki bu düşüşün yanısıra, KPB sırasında ve sonrasinda trombositlerin fonksiyonlarında da farklılıklar olduğu belirtilmiştir. Hastaların heparinize edilmesi de trombosit değerini etkileyen önemli bir nedendir. ${ }^{24}$ KPB esnasında hemodilüsyondan dolayı trombositlerin sayısı ortalama \% 50 oranında düşmektedir. Ayrıca yabancı yüzeyle temas etmesi ve hipotermiden dolayı trombositlerin fonksiyonlarında da bozukluklar oluşmaktadır. KPB gerçekleştirildiğinde kan veya kan ürünlerinin endotel ile kaplı olmayan, vücuttan farklı bir yüzeyle temas etmesi nedeniyle trombositlerin yanısıra kanın diğer şekilli elemanlarında da hasar meydana gelmektedir. ${ }^{25}$ Yaptığımız bu çalışmadaki platelet (PLT) değerlerini daha önceden yapılmış olan çalışmalarla paralel olduğunu gördük. Preoperatif ortalama PLT değerleri $272 \mathrm{bin} / \mathrm{mm}^{3}$ iken, aortik kross klemp sonrasında $158 \mathrm{bin} / \mathrm{mm}^{3 \prime} \mathrm{e}$ düştüğü, KPB çıkışında ise $154 \mathrm{bin} / \mathrm{mm}^{3} \mathrm{e}$ kadar düştüğünü tespit ettik. Bunun temel sebebinin hemodilüsyon, hastanın heparinize edilmesi ve yabancı materyal ile teması olduğunu düşündük. Postoperatif dönemde $262 \mathrm{bin} / \mathrm{mm}^{3} \mathrm{e}$ kadar yükseldiği ve bu ciddi artışın sebebinin vücudun kan üretimine başlaması ve yap1lan trombosit replasmanı olduğunu gözlemlemiş olduk.

KPB sonrası bir çok morbid durumun değerlendirilmesinde de hemogram parametrelerinden yararlanılabilmektedir. Son dönemlerde birçok çalışmada bu konunun önemine değinilmiştir. Bu çalışmalarda özellikle bazı hemogram parametre oranları kullanılmıştır. Bu konuyla ilgili Kotfis ve ark. ${ }^{26}$ yaptıkları çalışmada kalp cerrahisi sonrası postoperatif deliryumun öngörülmesinde beyaz hücreli inflamatuvar biyobelirteçlerin kullanımını araştırmışlardır. Çalışmalarında koroner arter bypass greft uygulanan hastaların verilerini analiz etmişlerdir. Lökosit (WBC) ve C-reaktif protein (CRP) konsantrasyonu ameliyat öncesi ve ameliyat sonrası farklı günlerinde post-operatif dönemde değerlendirmişlerdir. Deliryumu olan ve olmayan hastalar arasında nötrofil-lenfosit oranı (NLO), trombosit-lenfosit oranı (PLO) ve trombosit-WBC oranı (PWO) açısından farklılıkları değerlendirmişlerdir. Çalışmalarının sonucunda, daha düşük preoperatif PLO ve PWO düzeylerinin, kalp cerrahisi sonrası deliryum ile ilişkili olduğunu göstermişlerdir. Deliryum ile en güçlü korelasyonu preoperatif PWO'nun gösterdiğini ve postoperatif deliryum ile ilişkili potansiyel yeni bir biyobelirteç olabileceğini belirtmişlerdir. Başka çalışmalarda diğer morbid durumlarda da hemogram parametre oranlarının önemi belirtilmektedir. ${ }^{27,28}$ Kalp transplantas-yonu geçiren kalp yetmezliği hastalarında da nötrofil-lenfosit oranının (NLO) ve trombosit-lenfosit oranının (PLO) sonucu öngör- 
medeki rolü oldukça önemlidir. Yüksek NLO, hastane içi mortalite için bir prediktör ve 1 ylllık mortalite için bağımsız bir prognostik faktördür. Hem yüksek NLO hem de yüksek PLO, renal replasman tedavisi (RRT) için de prediktördür. ${ }^{27}$ Kardiyak cerrahide yüksek nötrofil, lenfosit ve trombosit sayılarının postoperatif akut böbrek hasarı ile ilişkili olduğunu ve ayrıca nötrofil, lenfosit ve trombosit oranlarının yüksek riskli kardiyovasküler cerrahide akut böbrek hasarı ve mortalitenin tahmin edilmesine yardımcı olabileceği bildirilmiştir. ${ }^{28} \mathrm{KPB}^{\prime} \mathrm{a}$ bağlı hemogram parametrelerindeki değişimlerin önceden belirlenmesi KPB esnası ve sonrası standart değişimler dışında gelişebilecek değişimlerin olası morbid durumları ortaya koyması ve risk durumlarının tespiti için oldukça önemlidir.

Çalışmamızda hemogram parametrelerindeki değişim istatistiksel olarak ciddi düzeyde anlamlıyd. KPB sirasinda hemogram parametrelerinin ciddi düzeyde azaldığını gördük. Hemogram düzeylerinde ki bu azalmaların KPB sirasında uygulanan prime solüsyon, verilen sıvilar, hastanın heparinize edilmesi ve enflamatuar yanıt ile ilişkili olabileceğini düşündük. Ayrıca, uygulanan kan akış hızına bağlı olarak da kan parametrelerinin yabancı yüzey ile daha fazla temas ettiği, daha yüksek basınca maruz kaldığı ve kan parametrelerinde daha fazla hasar ve hemoliz olduğu görüldü.

Sonuç olarak hastaya uygun olarak kan koruyucu yöntemlerin uygulanması, kanamaya sebep olacak faktörlerin önlenmesini sağlayacaktır. Aşırı aspirasyondan kaçınılarak, neden olacağı eritrosit yıkımından kaçınılması ve hastanın idrarla attığı sıvıya bağlı hemokonsantrasyon yapılması hastanın hematokrit değerinin normale gelmesini sağlayarak gereksiz kan replasmanını önleyecektir. Bu ilişkili faktörlerin saptanması ve düzeltilmesi ile komplikasyonların ve kötü sonuçların ortadan kaldırılması sağlanabilir, olası risk faktörleri saptanabilir ve sonuçlar iyileştirilebilir.

Çalışmamızın tek merkezli ve hasta sayısının az olması araştırmamızın sınırlılıkları arasında bulunmaktadır. Sonuçların daha geniş alanda daha fazla hasta ile tekrarlanmasının yararlı olacağını düşünmekteyiz.

Etik Komite Onayı: Çalışmamız Harran Üniversitesi Tıp Fakültesi Klinik Araştırmalar Etik Kurulu tarafindan onaylanmıştır (Tarih:23.11.2015, karar no:07).
Çıkar Çatışması: Yazarlar çıkar çatışması bildirmemektedir.

Yazar Katkıları: Fikir - BA, AK, MSA; Denetim AK, MSA; Malzemeler - BA; Veri Toplanması ve/ veya İşleme - BA; Analiz ve/veya Yorum - NK, MP, RD; Yazıyı yazan - BA.

Hakem değerlendirmesi: Dış bağımsız.

Finansal Destek: Bu çalışma Harran Üniversitesi BAP birimi Araştırma Fon Saymanlığı tarafından 15184 proje numarası ile desteklenmiştir.

\section{KAYNAKLAR}

1. As AK, Engin M, Türk T. Early-term results of early coronary artery bypass graft surgery in patients undergoing primary percutaneous coronary intervention due to acute coronary syndrome. Eur Res J. 2020. doi:10.18621/eurj.593369

2. Aftabuddin M, Rajbhandhari N, Rahman MZ, Islam N, Khan OS. Cardiopulmonary bypass induced hematological changes in patients undergoing cardiac surgery. Bangladesh Heart Journal. 2015;30(2):53-57. doi:10.3329/bhj.v30i2.28811

3. DeSomer F. Optimisation of the perfusion circuit and its possible impact on the inflammatory response. J Extra Corpor Tecnal. 2007;39:285-288.

4. Koçarslan A, Hazar A, Aydın MS, Aksoy N, Göz M. The impact of preoperative trimetazidine use on oxidative parameters in patients undergoing coronary bypass surgery. Dicle Medical Journal. 2013;40(4):589-596.

5. Aydınlı B, Demir A, Güçlü ÇY, et al. Hematological predictors and clinical outcomes in cardiac surgery. Journal of Anesthesia. 2016;30:770 -778 .

6. Karataş MB, Çanga Y, İpek G, et al. Association of admission serum laboratory parameters with new-onset atrial fibrillation after a primary percutaneous coronary intervention. Coron Artery Dis. 2016;27(2):128-134.

7. Pober JS, Cotran RS. Cytokines and endothelial cell biology. Physiol Rev. 1990;70(2):427-451.

8. DeBois WJ, Lee LY, Krieger KH. Safety of low hematocrits during cardiopulmonary bypass. Ann Thorac Surg. 2002;74(1):296-307.

9. Engin M. Are pre and postoperative platelet to lymphocyte ratio and neutrophil to lymphocyte ratio associated with early postoperative AKI following CABG? Braz J Cardiovasc Surg. 2020;35(2):239. doi:10.21470/1678-9741-20190482 
10. Erdolu B, As AK, Engin M. The relationship between the HATCH score, neutrophil to lymphocyte ratio and postoperative atrial fibrillation after off-pump coronary artery bypass graft surgery. Heart Surg Forum. 2020;23(1):E88-E92. doi:10.1532/hsf.2771

11. Çalışkan A, Yazıcı S, Karahan O, et al. The investigation of complete blood counting parameters in deep venous thrombosis. Dicle Medical Journal. 2014;41(1):118-122.

12. Larmann J, Handke J, Scholz AS, et al. Preoperative neutrophil to lymphocyte ratio and platelet to lymphocyte ratio are associated with major adverse cardiovascular and cerebrovascular events in coronary heart disease patients undergoing non-cardiac surgery. BMC Cardiovasc Disord. 2020;20(1):230. doi:10.1186/s12872-020 $-01500-6$

13. Salles FB, Kalil RAK. Platelet to lymphocyte ratio and neutrophil to lymphocyte ratio may contribute little compared to standard preoperative evaluation. Braz J Cardiovasc Surg. 2018;33 (6):644. doi:10.21470/1678-9741-2018-0242

14. Ivert T, Dalén M, Ander C, Stålesen R, Lordkipanidzé M, Hjemdahl P. Increased platelet reactivity and platelet-leukocyte aggregation after elective coronary bypass surgery. Platelets. 2019;30(8):975-981.

15. Bilal MS, Bayındır O, Erentürk S, et al. Roller ve santrifugal pompa tekniklerinin immun sistem üzerindeki etkilerinin karşılaştırılması. GKD Cer. Derg. 1995;3:17-26.

16. Rychly J, Oldag D, Krüger AD. Electrophoretic studies of the composition of peripheral mononuclear cells during operations with extracorporeal circulation. Z Exp Chir Transplant Kunstliche Organe. 1990;23(1):18-22.

17. Karkouti K, Wijeysundera DN, Yau TM, et al. The independent association of massive blood loss with mortality in cardiac surgery. Transfusion. 2004;44(10):1453-1462.

18. Çağdaş B, Yazıcıoğlu L, Eryılmaz S. Vücut dış1 yaşam desteğinde kan ve biyomateryel yüzeylerin etkileşimi. Turkiye Klinikleri Cardiovascular Surgery-Special Topics. 2017;(9)3:188-191.

19. Ganushchak YM, Fransen EJ, Visser C, DeJong DS, Maessen JG. Neurological complications after coronary artery bypass grafting related to the performance of cardiopulmonary bypass. Chest. 2004;125(6):2196-2205.
20.Lohrer RM, Trammer AR, Dietrich W, Hagl S, Linderkamp O. The influence of extracorporeal circulation and hemoseparationon red cell deformability and membrane proteins in coronery artery disease. J Thorac Cardiovasc Surg. 1990;99:735-740.

21.Habib RH, Zacharias A, Schwann TA, Riordan CJ, Durham SJ, Shah A. Adverse effects of low hematocrit during cardiopulmonary bypass in the adult: should current practice be changed? J Thorac Cardiovasc Surg. 2003;125(6):1438-50.

22. Balcı E, Aykut A, Sert GS, et al. Kalp cerrahisinde bir yıllık intraoperatif kan ürünü kullanımı analizi: Hangi hastalarda? Hangi ameliyatlarda? Ne kadar? GKDA Derg. 2016;22(2):62 -69. doi:10.5222/GKDAD.2016.062

23. Kalender M, Baysal AN, Dağlı M, Şahsıvar MA, Gökmengil H. Koroner arter baypas cerrahisi sirasında yapılan kan transfüzyonunun hastane mortalitesi üzerine etkisi. Koşuyolu Heart J. 2019;22(1):1-6. doi:10.5578/khj.67426

24. Ascione R, Caputo M, Angelini GD. Off-pump coronary artery bypass grafting: Not a flash pan. Ann Thorac Surg. 2003;75:306-313.

25.Zindrou D, Taylor KM, Bagger JP. Preoperative haemoglobin concentration and mortality rate after coronary artery bypass surgery. Lancet. 2002;359(9319):1747-1748.

26. Kotfis K, Ślozowska J, Safranow K, Szylińska A, Listewnik M. The practical use of white cell inflammatory biomarkers in prediction of postoperative delirium after cardiac surgery. Brain Sci. 2019;9(11):308. doi:10.3390/ brainsci9110308

27. Seropian IM, Romeo FJ, Pizarro R, et al. Neutrophil-to-lymphocyte ratio and platelet-tolymphocyte ratio as predictors of survival after heart transplantation. ESC Heart Fail. 2018;5 (1):149-156. doi:10.1002/ehf2.12199

28. Koo CH, Eun JD, Park YS, et al. Neutrophil, lymphocyte, and platelet counts and acute kidney injury after cardiovascular surgery. J Cardiothorac Vasc Anesth. 2018;32(1):212-222. doi:10.1053/j.jvca.2017.08.033 
Tablo 1. Hastaların tanımlayıcı verileri.

\begin{tabular}{|c|c|c|}
\hline & Min-Maks & Ort \pm S.S \\
\hline Yaş (yıl) & $17,00-71,00$ & $50,27 \pm 14,25$ \\
\hline Boy (cm) & $155,00-180,00$ & $165,33 \pm 0,06$ \\
\hline Kilo (kg) & $45,00-102,00$ & $71,00 \pm 12,98$ \\
\hline Vücut Yüzey Alanı $\left(\mathrm{m}^{2}\right)$ & $1,43-2,19$ & $1,78 \pm 0,17$ \\
\hline Flow (Akış Hızı) (ml) & $3780,00-5267,00$ & $4177,90 \pm 831,91$ \\
\hline Kross Klemp Süresi (dakika) & $20,00-128,00$ & $75,23 \pm 28,45$ \\
\hline Total Perfüzyon Süresi (dakika) & $38,00-235,00$ & $112,50 \pm 46,23$ \\
\hline Hastanede Kalış Süresi (gün) & $1,00-58,00$ & $13,53 \pm 10,18$ \\
\hline Yoğum Bakım Kalış Süresi (gün) & $1,00-12,00$ & $1,90 \pm 2,04$ \\
\hline Toplam, $\mathbf{n}=\mathbf{3 0}$ & & \\
\hline
\end{tabular}

Min-Maks: Minimum-Maksimum; Ort \pm S.S: Ortalama \pm Standart Sapma. 
Tablo 2. Farklı zamanlarda alınan hemogram örneklerinin karşılaştırılması.

\begin{tabular}{|c|c|c|c|c|c|c|}
\hline & $\begin{array}{c}\text { Preoperatif } \\
\text { (Servise Yatış) } \\
(\mathbf{N}=\mathbf{3 0})\end{array}$ & $\begin{array}{c}\text { Anestezi İn- } \\
\text { düksiyonu } \\
\text { Sonrası } \\
(\mathbf{N}=\mathbf{3 0})\end{array}$ & $\begin{array}{c}\text { Kross Klemp } \\
\text { Sonrası } \\
(\mathbf{N}=\mathbf{3 0})\end{array}$ & $\begin{array}{l}\text { KPB Çıkışı } \\
(\mathbf{N}=\mathbf{3 0})\end{array}$ & $\begin{array}{c}\text { Postoperatif } \\
\text { 5.Gün } \\
(\mathrm{N}=\mathbf{3 0})\end{array}$ & $\mathbf{p}^{\mathbf{x}}$ \\
\hline Lökosit, 10 $^{3 / u L}$ & $\begin{array}{l}9,04 \pm 2,38 \\
\mathrm{~B}^{* \mathrm{Y}}, \mathrm{C}^{* \mathrm{Y}}, \mathrm{D}^{* \mathrm{Y}}\end{array}$ & $\begin{array}{l}7,36 \pm 2,83 \\
\mathrm{~F}^{* \mathrm{Y}}, \mathrm{G}^{* \mathrm{Y}}\end{array}$ & $\begin{array}{l}5,78 \pm 2,94 \\
\mathrm{H}^{* \mathrm{Y}}, \dot{I}^{* \mathrm{Y}}\end{array}$ & ${ }_{Y} 14,10 \pm 6,37$ & ${ }_{Y}^{13,30 \pm 6,79}$ & 0,000 \\
\hline Nötrofil, $10^{3 / u L}$ & $5,89 \pm 2,29$ & $4,82 \pm 2,37$ & $4,00 \pm 2,74$ & $\begin{array}{l}3,89 \pm 2,07 \\
Y\end{array}$ & ${ }_{Y}^{10,45 \pm 5,75}$ & 0,394 \\
\hline Lenfosit, $10^{3 / u L}$ & $\begin{array}{l}2,27 \pm 0,76 \\
A^{* Y}, B^{* Y}, C^{* Y}\end{array}$ & $1,74 \pm 0,63$ & $\begin{array}{l}1,40 \pm 0,46 \\
\mathrm{H}^{* \mathrm{Y}}, \mathrm{I}^{* \mathrm{Y}} \\
\end{array}$ & ${ }_{Y}^{1,81 \pm 0,71}$ & ${ }_{Y}^{1,95 \pm 1,03}$ & $\mathbf{0 , 0 0 0}$ \\
\hline Monosit, 10 $^{3 / u L}$ & $\begin{array}{l}0,63 \pm 025 \\
\mathrm{~B}^{* \mathrm{Y}}, \mathrm{C}^{* \mathrm{Y}}, \mathrm{D}^{* \mathrm{Y}}\end{array}$ & $\begin{array}{l}0,56 \pm 0,33 \\
E^{* Y}, F^{* Y}, G^{* Y}\end{array}$ & $\begin{array}{l}0,28 \pm 0,15 \\
\dot{I}^{*} \mathrm{Y}\end{array}$ & $\begin{array}{l}0,31 \pm 0,24 \\
\mathrm{~K}^{* \mathrm{Y}}\end{array}$ & $\begin{array}{l}0,84 \pm 0,49 \\
\mathrm{Y}\end{array}$ & $\mathbf{0 , 0 0 0}$ \\
\hline Eoznofil, 10 ${ }^{3 / u L}$ & $\begin{array}{l}0,23 \pm 0,16 \\
\mathrm{~B}^{* \mathrm{Y}}, \mathrm{C}^{* \mathrm{Y}}\end{array}$ & $0,15 \pm 0,18$ & $\begin{array}{l}0,08 \pm 0,09 \\
\dot{I} * \mathrm{Y}\end{array}$ & $\begin{array}{l}0,09 \pm 0,11 \\
\mathrm{~K}^{* \mathrm{Y}}\end{array}$ & $\begin{array}{l}0,21 \pm 0,29 \\
\mathrm{Y}\end{array}$ & 0,004 \\
\hline Bazofil, 10 ${ }^{3 / u L}$ & $\begin{array}{l}0,07 \pm 0,03 \\
\mathrm{Y}\end{array}$ & $\begin{array}{l}0,07 \pm 0,07 \\
\text { Y }\end{array}$ & $\begin{array}{l}\text { Y, } \\
\text { Y }\end{array}$ & $\begin{array}{l}0,16 \pm 0,56 \\
\text { Y }\end{array}$ & $\underset{\mathrm{Y}}{2,24 \pm 11,84}$ & 0,412 \\
\hline Eritrosit, $10^{6 / u L}$ & $\begin{array}{l}5,05 \pm 0,45 \\
A^{* Y}, B^{* Y}, C^{* Y}, \\
D^{* Y}\end{array}$ & $\begin{array}{l}4,31 \pm 0,65 \\
E^{* Y}, F^{* Y}, G^{* Y}\end{array}$ & $\begin{array}{l}2,97 \pm 0,45 \\
\dot{\mathrm{I}} * \mathrm{Y}\end{array}$ & ${ }_{Y}^{3}, 11 \pm 0,23$ & ${ }_{Y}^{3,34} \pm 0,69$ & $\mathbf{0 , 0 0 0}$ \\
\hline Hematokrit, \% & $\begin{array}{l}41,28 \pm 7,30 \\
\mathrm{~A}^{* \mathrm{Y}}, \mathrm{B}^{* \mathrm{Y}}, \mathrm{C}^{* \mathrm{Y}}, \\
\mathrm{D}^{* \mathrm{Y}}\end{array}$ & $\begin{array}{l}36,24 \pm 6,33 \\
E^{* Y}, F^{* Y}, G^{* Y}\end{array}$ & $\begin{array}{l}24,91 \pm 4,39 \\
\dot{I}^{* Y}\end{array}$ & $\begin{array}{l}26,28 \pm 2,37 \\
\mathrm{~K}^{* \mathrm{Y}}\end{array}$ & $\underset{\mathrm{Y}}{29,36 \pm 3,70}$ & $\mathbf{0 , 0 0 0}$ \\
\hline $\begin{array}{l}\text { Hemoglobin, g/ } \\
\text { dL }\end{array}$ & ${ }_{Y} 13,69 \pm 1,87$ & ${ }_{Y}^{5,58 \pm 2,42}$ & ${ }_{Y}^{8,15 \pm 1,63}$ & $\underset{\mathrm{Y}}{8,59 \pm 0,87}$ & $\underset{\mathrm{Y}}{9,58 \pm 1,31}$ & 0,366 \\
\hline Platelet, $\mathbf{1 0}^{3 / \mathrm{uL}}$ & $\begin{array}{l}272,45 \pm 72,44 \\
\mathrm{~A}^{* \mathrm{Y}}, \mathrm{B}^{* \mathrm{Y}}, \mathrm{C}^{* \mathrm{Y}}\end{array}$ & $\begin{array}{l}231,56 \pm 61,00 \\
E^{* Y}, F^{* Y}\end{array}$ & $\begin{array}{l}158,44 \pm 61,34 \\
\dot{I}^{*} \mathrm{Y}\end{array}$ & $\begin{array}{l}154,61 \pm 43,23 \\
K^{* Y}\end{array}$ & $262,76 \pm 102,11$ & $\mathbf{0 , 0 0 0}$ \\
\hline
\end{tabular}

X: ANOVA testi; Y: Eşleştirilmiş t-testi; A: Preoperatif dönemdeki düzey ile anestezi indüksiyonu sonrası dönemdeki düzeyin karşılaştırılması; B: Preoperatif dönemdeki düzey ile kross klemp sonrası dönemdeki düzeyin karşılaştırılması; C: Preoperatif dönemdeki düzey ile KPB çıkışı dönemindeki düzeyin karşılaştırılması; D: Preoperatif dönemdeki düzey ile postoperatif 5.gündeki düzeyin karşılaştırılması; E: Anestezi indüksiyonu sonrası dönemdeki düzey ile kross klemp sonrası dönemdeki düzeyin karşılaştırılması; F: Anestezi indüksiyonu sonrası dönemdeki düzey ile KPB çıkışı dönemindeki düzeyin karşılaştırılması; G: Anestezi indüksiyonu sonrası dönemdeki düzey ile postoperatif 5. gündeki düzeyin karşılaştırılması; H: Kross klemp sonrası dönemdeki düzey ile KPB çıkışı dönemindeki düzeyin karşılaştırılması; İ: Kross klemp sonrası dönemdeki düzey ile postoperatif 5.gündeki düzeyin karşılaştırılması; K: KPB çıkışı dönemdeki düzey ile postoperatif 5.gündeki düzeyin karşılaştırılması; *:p < 0,05. 
Tablo 3. Hemogram parametreleri ile sıvı miktarları arasındaki korelasyon.

\begin{tabular}{|c|c|c|c|c|}
\hline & & $\begin{array}{l}\text { Verilen Sıvı } \\
\text { Miktarı, ml }\end{array}$ & $\begin{array}{c}\text { Sıvı Çıkış Miktarı, } \\
\text { ml }\end{array}$ & $\begin{array}{c}\text { Sıvı Dengesi, } \\
\mathrm{ml}\end{array}$ \\
\hline \multirow[t]{2}{*}{ Lökosit, 10 } & $\mathrm{r}$ & $0,328^{* *}$ & $-0,028^{* *, *}$ & $0,288^{* *}$ \\
\hline & $\mathrm{p}$ & $\mathbf{0 , 0 0 0}$ & 0,734 & 0,001 \\
\hline \multirow[t]{2}{*}{ Nötrofil, $10^{3 / u L}$} & $\mathrm{r}$ & $0,416^{k * k}$ & $-0,035^{* * * *}$ & $0,374^{* * *}$ \\
\hline & $\mathrm{p}$ & 0,000 & 0,671 & 0,000 \\
\hline \multirow[t]{2}{*}{ Lenfosit, $10^{3 / u L}$} & $\mathrm{r}$ & $-0,233^{*}$ & 0,016 & $-0,231^{*}$ \\
\hline & $\mathrm{p}$ & 0,010 & 0,849 & 0,011 \\
\hline \multirow[t]{2}{*}{ Monosit, $10^{3 / u L}$} & $\mathrm{r}$ & $-0,417^{* *}$ & $-0,011^{* *}$ & $-0,424^{* *}$ \\
\hline & $\mathrm{p}$ & 0,000 & 0,893 & 0,000 \\
\hline \multirow[t]{2}{*}{ Eoznofil, $10^{3 / u L}$} & $\mathrm{r}$ & $-0,292^{* *}$ & $0,014^{k * k}$ & $-0,284^{k * k}$ \\
\hline & $\mathrm{p}$ & 0,001 & 0,868 & 0,002 \\
\hline \multirow[t]{2}{*}{ Eritrosit, $10^{6 / u L}$} & $\mathrm{r}$ & $-0,715^{* *}$ & $-0,065^{* * *}$ & $-0,680^{* * *}$ \\
\hline & $\mathrm{p}$ & 0,000 & 0,428 & 0,000 \\
\hline \multirow[t]{2}{*}{ Hematokrit, \% } & $\mathrm{r}$ & $-0,626^{* *}$ & $-0,066^{* *}$ & $-0,593^{* * *}$ \\
\hline & $\mathrm{p}$ & 0,000 & 0,420 & 0,000 \\
\hline \multirow{2}{*}{$\begin{array}{l}\text { Hemoglobin, g/ } \\
\text { dL }\end{array}$} & $\mathrm{r}$ & $-0,055$ & $-0,008^{*}$ & $-0,056$ \\
\hline & $\mathrm{p}$ & 0,549 & 0,919 & 0,547 \\
\hline \multirow[t]{2}{*}{ Platelet, $10^{3 / \mathrm{uL}}$} & $\mathrm{r}$ & $-0,526^{* *}$ & $0,273^{* * *}$ & $-0,490^{* *}$ \\
\hline & $\mathrm{p}$ & $\mathbf{0 , 0 0 0}$ & 0,001 & $\mathbf{0 , 0 0 0}$ \\
\hline
\end{tabular}

r: Pearson korelasyon analiz testi; *: Korelasyon 0.05 düzeyinde anlamlı; **: Korelasyon 0.01 düzeyinde anlaml. 